〈論文〉

\title{
不織布担体の好気性微生物付着機構に関する研究
}

\author{
油科 嘉 則* 長 谷 川 潤*
}

\section{Studies of Aerobic Microbial Attachment Mechanism on Nonwoven Fabrics Carriers}

\author{
Yoshinori YUSHINA* and Jun HASEGAWA*
}

* Research \& Development Center, Chiyoda corporation, 3-13 Moriya-cho, Kanagawa-ku, Yokohama 221 Japan

\begin{abstract}
In a wastewater treatment process using attached microorganisms, microbial carriers such as plastic resins, porous ceramics, sands etc. have conventionally been employed. Since the performance of the biological wastewater treatment has been regarded as a function of the concentration of microorganisms in a reactor, microbial carriers have been focused on to increase the specific surface area. The fluidized bed process ${ }^{1,2)}$ using small particles is one example of the application.

Nonwoven fabrics made of plastic resin are considered highly effective microbial carriers because of the attachment of microorganisms on each thread as well as microbial growth in three dimensional intertwisted spaces. However, there have been few reports on the application of nonwoven fabrics as aerobic microbial carriers.

Experimental studies have been conducted to clarify the features of attachment of microorganisms to nonwoven fabrics by the initial phase filtration test, the intial phase bioattachment test in a reactor and the continuons biofilm growth test.

The highest concentration of attached microbes has been found to be attainable in a specific range of the opening length rather than over a specific surface area. The composition difference of the attached microbes compared with the suspended microbes had a great effect on the kinetic constants.
\end{abstract}

Key words : microbial carrier, nonwoven fabrics, aerobic microbial attachment, microbial compostition, kinetic constants

\section{1.はじめに}

生物膜法は高濃度に微生物を維持でき運転管理が容 易であり，浸漬沪床法，流動床法，回転円板法など排 水処理分野に広く適用されている。本法では生物膜を 形成させるために微生物担体として, 砂, 活性炭等の 粒子をはじめとしてポーラスなセラミックまた合成樹 脂を素材とする板, 系, 粒子等が使用されている。合 成樹脂板の担体では比表面積を大きくするために形状 について種々の工夫が成されてきている。また微小粒
状担体を使用した流動床式生物処理装置 ${ }^{1,2}$ は担体の 比表面積を大きくとることによって微生物の保持量を 高くした高性能バイオリアクターの一例である。この ように生物膜法に沶いては担体の比表面積をいかに大 きくするかに力が注がれてきた経緯がある3)。

本研究では微生物担体として合成樹脂の不織布を使 用する試みを行った。不織布は一本一本の繊維が織り なす複雑な立体空間を作っている。不織布の比表面積 を糸の表面積の和としてとらえると, 合成樹脂不織布 は比表面積が大きくかつ素材の占める充填率が低い特 
徵を有している。したがって, 糸表面への微生物付着 拈よび不織布の立体空間での微生物増殖により, 高濃 度微生物集積が期待でき微生物担体としての応用が考 光られる。

しかし, 好気性条件下での不織布担体の微生物付着 機構（初期沪過, 生物膜形成, 微生物増殖, 剝離) 飞 扔いて, 微生物の集積が不織布担体を構成する糸の比 表面積に関係するのか, 不織布の目開き間隔によるの か, さらに集積した微生物の組成は浮遊微生物とはど のように異なるかについては明らかになっていない部 分が多い。

そこで, 本研究では担体として不織布を使用した場 合の好気性微生物の付着敊よび担体特性との関係につ いて多面的に検討を行った。すなわち，不織布担体へ の微生物付着特性を解明するために好気性条件下で夕 ンパク系排水と各種目開き間隔を有する不織布担体を 使用して，1)不織布の初期汇過特性，2)不織布の立 体格子モデルを使用した比表面積, 目開き間隔と微生 物付着濃度の関係, 3 ) 微生物組成の経時変化, 4 ) 付 着扣よび浮遊微生物の基質分解の動力学的解析などを 実験的に調べた。この結果, 有用な知見を得たのでこ こに報告する。

\section{2．実験装置および実験方法}

\section{1 初期沪過テスト}

不織布の初期沪過テスト装置のフローシートを Fig. 1 亿示す。 2.3 微生物付着実験で使用するのと

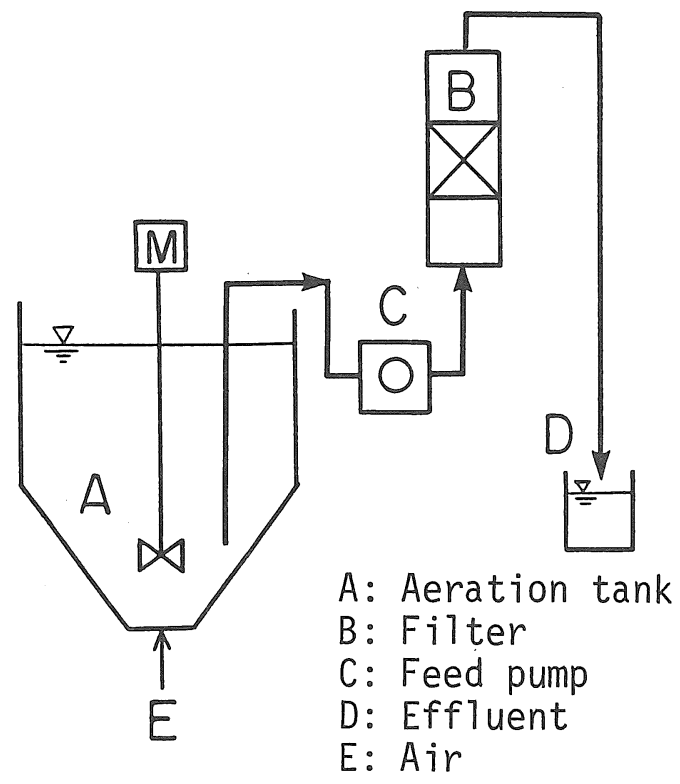

Fig. 1 Flow sheet of filtration test.
同じ不織布を一辺 $100 \mathrm{~mm}$ の立方体として初期沪過テ ストに供試した。Table 1 に不織布の性状を示すが，目 開き間隔拉よび比表面積は不織布の立体格子モデルを 使用した計算值である。本テストは使用した不織布の 目開き間隔が0.54〜 4.7mm の範囲にあり, 不織布の微 生物付着機構のらち初期沪過が不織布の表面あるいは 層内部にて行われているかを把握するために行った。 流入水 SS 濃度として $190 \mathrm{mg} \cdot l^{-1}$ の微生物を含む曝気 槽内の液を使用して, 沪過槽内の液通過速度 $10 \mathrm{~m} \cdot \mathrm{h}^{-1}$ で通液し装置内の液体が置き変わる 2 分後の処理水の SS 濃度を分析した。

\section{2 立方格子モデルによる目開き間隔の算出}

不織布が同一の采の太さよりなる立方格子空間によ り構成されるとした立方格子モデルにより目開き間隔 を算出した。立方体の不織布担体の一辺の長さ $l$ を分 割数 $n$ で除したものが立方格子の一辺の長さ $\beta$ であ り, Fig. 2 に示すように $\beta$ は糸の太さ $d$ と目開き間隔 $\alpha$ の和となる。ここで $L$ は不織布担体を構成する糸の 総延長, $W$ はその重量, $\gamma$ は不織布素材の真密度, $\varepsilon$ は不織布の素材の充填率である。

$$
\begin{aligned}
& \beta=l \cdot n^{-1} \\
& L=\beta \cdot 3 n(n+1)^{2} \\
& n=L^{0.5} \cdot(3 l)^{-0.5}-1 \\
& W=0.25 \pi d^{2} \cdot L \cdot \gamma \\
& \varepsilon=W \cdot l^{-3} \cdot \gamma^{-1}
\end{aligned}
$$$$
\text { (1), (2)より } \quad n=L^{0.5} \cdot(3 l)^{-0.5}-1
$$

式(1)〜(5)より目開き間隔は式(6)で表される。

$$
\alpha=\left(2 \cdot(3 \pi)^{-0.5} \cdot \varepsilon^{0.5} \cdot d^{-1}-l^{-1}\right)^{-1}-d
$$

不織布担体の一辺の長さ $l$ より糸の太さ $d$ が十分小 さい場合は次式(7)にて表される。

$$
\alpha \doteqdot\left(0.5 \cdot(3 \pi)^{0.5} \cdot \varepsilon^{-0.5}-1\right) \cdot d
$$

一方, 比表面積 $a$ は不織布担体を構成する系の全表面 積を不織布担体の体積にて除した值として求められ る。

$$
a=\pi d \cdot L \cdot l^{-3}=4 \cdot \varepsilon \cdot d^{-1}
$$

\section{3 微生物付着実験}

Fig.3 に実験装置のフローシートを示す。基質とし てはペプトン・魚肉エキスを主体とした合成排水を使 用した。その組成执よび性状を Table 2 亿示す。曝気槽 は外径 $680 \mathrm{~mm}$, 高さ $660 \mathrm{~mm}$ のコーン部を有する円筒

Table 1 Characteristics of five different nonwoven fabrics carriers.

\begin{tabular}{|c|c|c|c|c|}
\hline $\begin{array}{c}\text { Carrier } \\
\text { number }\end{array}$ & $\begin{array}{c}\text { Thread } \\
\text { diameter } \\
(\mathrm{mm})\end{array}$ & $\begin{array}{l}\text { Void } \\
\text { ratio }\end{array}$ & $\begin{array}{c}\text { Opening } \\
\text { length* } \\
(\mathrm{mm})\end{array}$ & $\begin{array}{c}\text { Specific } \\
\text { surface area* } \\
\left(\mathrm{m}^{-1}\right)\end{array}$ \\
\hline 1 & 0.66 & 0.965 & 4.7 & 220 \\
2 & 0.66 & 0.940 & 3.5 & 370 \\
3 & 0.25 & 0.961 & 1.7 & 630 \\
4 & 0.25 & 0.941 & 1.3 & 950 \\
5 & 0.08 & 0.962 & 0.54 & 1950 \\
\hline
\end{tabular}

*: Calculated value 


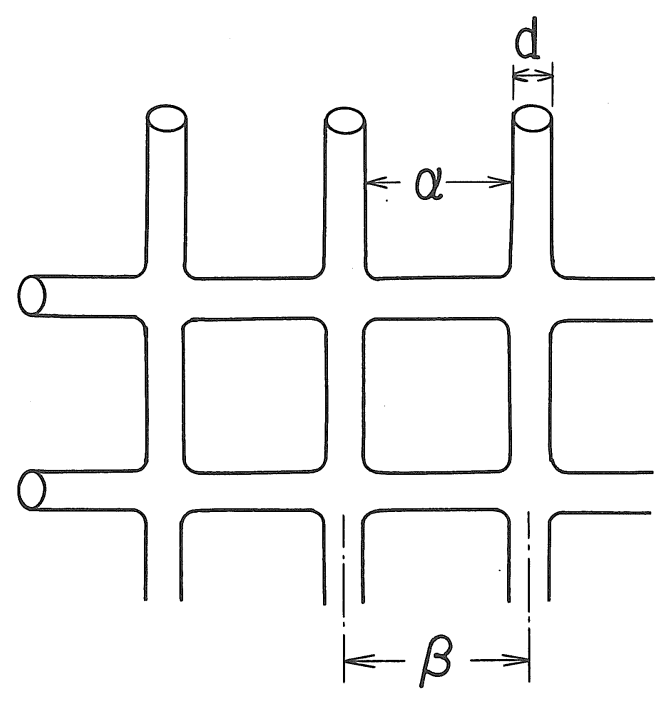

Fig. 2 Three dimensional lattice model for nonwoven fabrics.

型で外周に沈殿部が設けられ中心に曝気用のドラフト チューブがある。曝気槽全容積は $135 l$ でそのらち外周 の沈殿部は $70 l$ である。

この曝気槽内に Fig. 4 に示す不織布担体のホル ダー，合成樹脂板サンプル和よび系状サンプル各 5 セットをそれぞれ円周方向に並べ，垂直に設置した。 実験に使用したホルダーは 5 種類の不織布（大きさ 70 $\mathrm{mm} \times 90 \mathrm{~mm}$, 厚さ $10 \mathrm{~mm}$ ) 間に $10 \mathrm{~mm}$ の水路部を設け, 装置内の水流が均一になるようにした。またTable 1 に示したよらにポリ塩化ビニリデン製不織布担体の性 状は目開き間隔 $0.45 \sim 4.7 \mathrm{~mm}$ ，空吵率0.94〜0.96，糸 の太さ0.08〜0.66mm であった。同様に，合成樹脂板 サンプルは大きさ $40 \mathrm{~mm} \times 158 \mathrm{~mm}$, 厚さ $3 \mathrm{~mm}$ の Table 3 に示すテフロン, ポリプロピレン, ナイロン 6 , ポリ エチレン，ポリ塩化ビニルの平滑な合成樹脂板 5 枚を 1 セットとした。表中の接触角は $10 \mu l$ の蒸留水を各サ ンプル表面に滴下し, その液滴形状より算出した ${ }^{4,5)}$ 。 さらに, 付着微生物の走査型電子顕微鏡写真 (SEM) 観察用に合成樹脂製の長さ $100 \mathrm{~mm}$ の糸を同様にセッ トした。

流入排水は $\mathrm{BOD}$ 約 $350 \mathrm{mg} \cdot l^{-1}$ 濃度で流量 $3 l \cdot \mathrm{h}^{-1}$ で 暴気槽へ供給した。実験は常温で行い, $\mathrm{pH}$ 制御は行わ なかった。本実験中定期的に流入水, 流出水の BOD, $\mathrm{COD}_{\mathrm{Mn}}, \mathrm{SS}$ を測定した。ペプトン・魚肉エキス基質を 用いて 1 カ月馴養した活性污泥を, 初期 MLSS 濃度 $2,000 \mathrm{mg} \cdot l^{-1}$ に調製して, Fig.3 に示す装置に供給し, 不織布ホルダー，板，糸を浸漬し実験を開始した。不 織布は 1 セットづつを 6 週間まで順次取り出し付着微

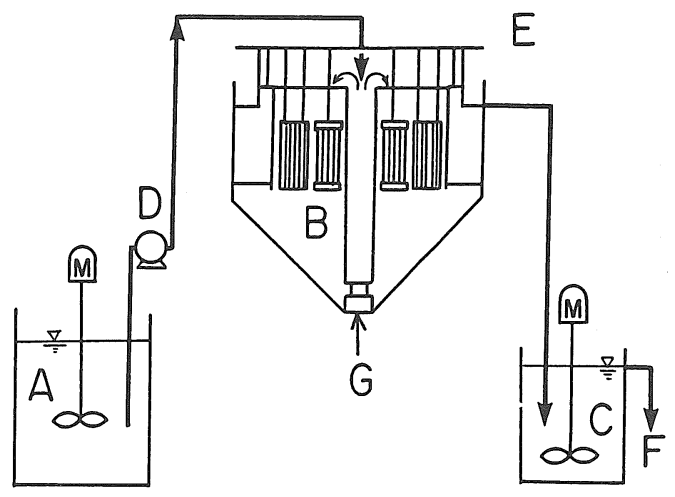
A: Raw water tank
B: Aeration tank
C: Recejving tank
$E$ : Nonwoven fabrics
D: Feed pump
$F$ : Effluent
G: Air

Fig. 3 Flow sheet of experimental apparatus.

Table 2 Characteristics of synthetic waste water.

\begin{tabular}{|l|r|l|r|}
\hline Peptone & 310 & BOD & 350 \\
Fish meat extracts & 170 & COD & 90 \\
Sucrose & 40 & SS & 50 \\
$\mathrm{Na}_{2} \mathrm{HPO}_{4}$ & 35 & TOC & 170 \\
$\mathrm{CaCl}_{2}$ & 35 & & \\
$\mathrm{NaCl}^{\text {Urea }}$ & 18 & Protein & 181 \\
$\mathrm{MgSO}_{4}$ & 9 & Carbohydrate & 4 \\
\hline
\end{tabular}

unit : $\mathrm{mg} \cdot \mathrm{l}^{-1}$

生物重量, 微生物組成を分析した。をた合成樹脂板, 糸を適宜取り出し各々付着微生物重量測定, SEM を 撮影した。

一連の連続実験の間に, 第 6 週目の各不織布への付 着微生物と曝気槽内の浮遊微生物を採取し，2種類の 微生物と連続実験で使用した基質を用いて回分テスト を行い, DOCを指標とした基質除去に関する動力学的 解析を行った。

\section{4 分析項目}

分析項目としては, 以下に挙げるものをカッコ内の 分析法で分析した。流入水, 流出水の $\mathrm{pH}$ (ガラス電極 法), BOD (JISK0102-1986，21), COD SS (同, 14.1), TOC (燃焼一非分散系赤外線式ガス 分析法）扣よび微生物組成の分析6)はンパク質 (Lowry 法), 炭水化物（フェノール硫酸法），核酸 (Schneider 法による分解抽出の UV 吸収定量法) に よった。担体付着の SS, VSS は担体サンプルを蒸留水 中で剥離し, MLSS, MLVSS 測定(下水道試験法, 1984 年版)に準拠した。さらに, SEM による付着微生物な らびに浮遊微生物の観察も行った。 


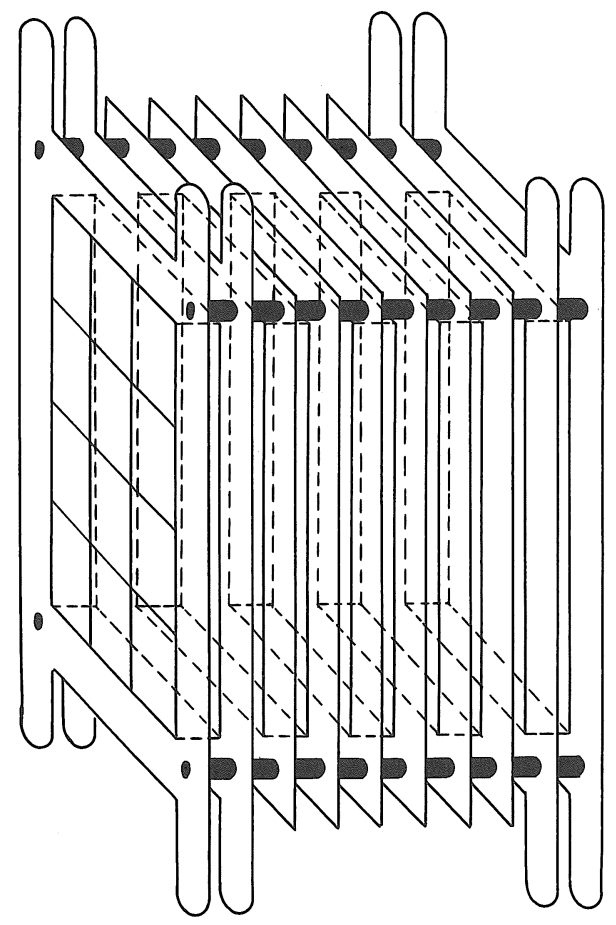

Fig. 4 Nonwoven fabrics holder.

\section{3. 実験 結 果}

\section{1 初期沪過テスト}

Table 4 に不織布の初期沪過テスト結果を示す。 5 種類の目開き間隔の異なる不織布の初期沪過の SS 除 去率は28～86\%であった。テスト中最も目開き間隔が 小さい担体 No. 5 に扔いては不織布の流入側に SS 層 が形成され表層沪過が進行していることが観察され た。一方, 他の 4 種類の担体では SS 層の形成はなく, 表層沪過は観察されなかった。

\section{2 微生物付着実験}

Fig. 5 にペプトン・魚肉エキス基質合成排水の処理 運転結果を流入水, 流出水の $\mathrm{BOD}, \mathrm{COD}_{\mathrm{Mn}}, \mathrm{SS}$ の経 時変化として示す。実験期間中の水温は $20 \sim 24^{\circ} \mathrm{C}$ であ

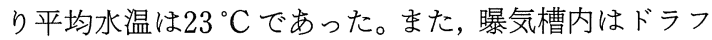
トチューブ流出水 DO が $6 \mathrm{mg} \cdot \mathrm{l}^{-1}$ 以上と好気状態が 保たれ， $\mathrm{pH}$ 範囲は7.0 8.0であった。平均容積負荷 $0.4 \mathrm{~g}-\mathrm{BOD} \cdot l^{-1} \cdot \mathrm{d}^{-1}$ にて運転し, 流出水 $\mathrm{BOD}$ 濃度 21 $\mathrm{mg} \cdot l^{-1}$, 平均 BOD 除去率 $93 \%$ とほぼ安定した処理が 行われた。不織布への付着物は薄茶色を呈し, やや粘 着性であった。発生污泥の引抜きは本実験期間中実施 しなかった。

Fig. 6 亿不織布担体の付着微生物濃度をVSS 濃度 として表し，目開き間隔の影響と経過時間による推移
Table 3 Contact angle of plate samples.

\begin{tabular}{|l|c|}
\hline \multicolumn{1}{|c|}{ Material } & Contact angle* \\
\hline Teflon & $104^{\circ}$ \\
Polypropylene & $92^{\circ}$ \\
Nylon 6 & $88^{\circ}$ \\
Polyetylene & $86^{\circ}$ \\
Polyvinyl chloride & $73^{\circ}$ \\
\hline
\end{tabular}

*: measured by water drops method

Table 4 Effect of opening length on initial filtration.

\begin{tabular}{|c|c|c|c|}
\hline $\begin{array}{c}\text { Carrier } \\
\text { number }\end{array}$ & $\begin{array}{c}\text { Opening } \\
\text { length* }(\mathrm{mm})\end{array}$ & $\begin{array}{c}\text { Effluent SS } \\
\left(\mathrm{mg} \cdot \mathrm{l}^{-1}\right)\end{array}$ & $\begin{array}{c}\text { Removal } \\
\text { percentage }(\%)\end{array}$ \\
\hline 1 & 4.7 & 137 & 28 \\
2 & 3.5 & 117 & 38 \\
3 & 1.7 & 77 & 60 \\
4 & 1.3 & 50 & 74 \\
5 & 0.54 & 26 & 86 \\
\hline
\end{tabular}

Influent $S S=190 \mathrm{mg} \cdot \mathrm{l}^{-1}$, Filter depth $=100 \mathrm{~mm}$ *: Calculated value

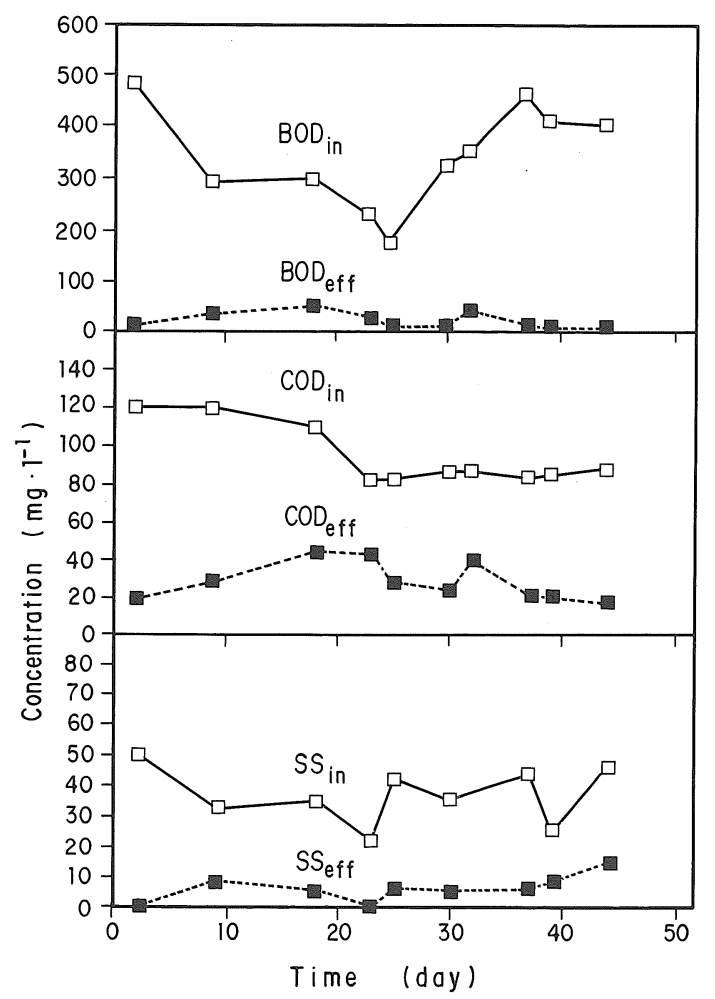

Fig. 5 Changes in BOD, COD and SS vs. time.

を 3 次元グラフとして示す。第 1 週目では，一番小さ い目開き間隔の担体 No. 5 が最も高い付着 VSS 濃度 を示し初期沪過特性結果と同様の傾向を表している。 
第 2 週目以降, 目開き間隔 $1.3 \mathrm{~mm}$ の担体 No. 4 が最高 付着 VSS 濃度を達成し，第 6 週目をで継続して最高 值を保った。このことから不織布担体の目開き間隔に 最も微生物が高濃度に付着しやすい至適範囲が存在す ることがわかった。すなわら，本実験で採用した平均 容積負荷 $0.4 \mathrm{~g}-\mathrm{BOD} \cdot l^{-1} \cdot \mathrm{d}^{-1}$ の条件下では目開き間隔 $1.3 \mathrm{~mm}$ 近傍の不織布担体が最高の VSS 付着濃度を 示した。

付着微生物と浮遊微生物の組成がどのように経時的



Fig. 6 Profile of microbial attachment on nonwoven fabrics carriers.
変化してくるのかを検討した結果を一括して Table 5,6 に示寸。微生物の組成はタンパク質, 炭水化物, 核酸，脂質，灭分として表されるが，本実験ではタン パク質，炭水化物，核酸について分析し各成分濃度沶 よび VSS, MLVSS 当りの各成分の比率を求めた。付 着微生物ではタンパク質濃度の変化が VSS 濃度の変 化に影響を与えて扣り，また核酸濃度は余り大きな変 化はなかった。付着微生物の VSS/SS 比は0.81以上と 高い值であった。浮遊微生物について, MLVSS/ MLSS 比は0.40〜0.76であり液中に含まれる塩分な どが影響を与えている。付着微生物のVSSに対して のタンパク質, 炭水化物, 核酸の比率の合計は打よそ 90\%を示した。一方，浮遊微生物の MLVSS に対して の 3 成分の比率の合計は70\%であった。これは MLVSS には液中の色度成分などの生物難分解物質等 が含まれているためと考えられる。

\section{3 回分テスト}

不織布担体に付着した微生物と曝気槽内の浮遊微生 物を遠心分離し濃縮されたものを用いて，ペプトン・ 魚肉エキス基質液の溶解性有機炭素（DOC）の減少を 経時的に測定した結果を Fig.7に示す。回分テスト開 始時の VSS 濃度は付着微生物 $\left(370 \mathrm{mg}-\mathrm{VSS} \cdot l^{-1}\right)$ と浮

Table 5 Results of attached microbial composition analysis as a function of time.

\begin{tabular}{|c|c|c|c|c|c|c|c|c|c|c|c|}
\hline $\begin{array}{l}\text { Carrier } \\
\text { number }\end{array}$ & $\begin{array}{l}\text { Time } \\
\text { (week) }\end{array}$ & $\begin{array}{c}\text { Protein } \\
\left(\mathrm{g} \cdot \mathrm{l}^{-1} \text { carrier }\right)\end{array}$ & $\begin{array}{l}\text { Carbohydrate } \\
\text { (g. } \text { - }^{-1} \text { carrier) }\end{array}$ & $\begin{array}{l}\text { Nucleic acid } \\
\left(\mathrm{g} \cdot \mathrm{l}^{-1} \text { carrier) }\right.\end{array}$ & $\begin{array}{c}\text { SS } \\
\left(\mathrm{g} \cdot \mathrm{l}^{-1} \text { carrier }\right)\end{array}$ & $\begin{array}{c}\text { VSS } \\
\left(\mathrm{g} \cdot \mathrm{1}^{-1} \text { carrier }\right)\end{array}$ & $\begin{array}{c}\text { Protein } \\
\text { /NSS }\end{array}$ & $\begin{array}{c}\text { Carbohydrate } \\
\text { /VSS }\end{array}$ & $\begin{array}{l}\text { Nucleic acid } \\
\text { /VSS }\end{array}$ & SUM.* & VSS/SS \\
\hline \multirow{4}{*}{1} & 1 & 1.33 & 0.41 & 0.12 & 2.09 & 2.07 & 0.64 & 0.20 & 0.06 & 0.90 & 0.99 \\
\hline & 2 & 2.41 & 0.62 & 0.22 & 4.03 & 3.47 & 0.69 & 0.18 & 0.06 & 0.93 & 0.86 \\
\hline & 3 & 2.28 & 0.61 & 0.17 & 4.14 & 3.35 & 0.68 & 0.18 & 0.05 & 0.91 & 0.81 \\
\hline & 4 & 3.73 & 1.17 & 0.28 & $\begin{array}{l}6.90 \\
4.14\end{array}$ & $\begin{array}{l}5.64 \\
3.44\end{array}$ & $\begin{array}{l}0.66 \\
0.80\end{array}$ & $\begin{array}{l}0.21 \\
0.21\end{array}$ & $\begin{array}{l}0.05 \\
0.03\end{array}$ & $\begin{array}{l}0.92 \\
1.04\end{array}$ & $\begin{array}{l}0.82 \\
0.83\end{array}$ \\
\hline \multirow{5}{*}{2} & $\frac{6}{1}$ & 2.75 & 0.73 & $\frac{0.12}{0.10}$ & $\frac{4,14}{2.09}$ & $\frac{3.44}{1.74}$ & 0.57 & 0.19 & 0.06 & 0.82 & 0.83 \\
\hline & $\frac{1}{2}$ & $\begin{array}{l}0.99 \\
2.72\end{array}$ & $\begin{array}{l}0.33 \\
0.65\end{array}$ & $\begin{array}{l}0.10 \\
0.23\end{array}$ & 4.30 & 3.78 & 0.72 & 0.17 & 0.06 & 0.95 & 0.88 \\
\hline & 3 & 2.18 & 0.65 & 0.16 & 4.34 & 3.51 & 0.62 & 0.19 & 0.05 & 0.86 & 0.81 \\
\hline & 4 & 5.46 & 1.52 & 0.36 & 9.39 & 7.88 & 0.69 & 0.19 & 0.05 & 0.93 & 0.84 \\
\hline & 6 & 3.41 & 0.82 & 0.17 & 5.34 & 4.40 & 0.78 & 0.19 & 0.04 & 1.01 & 0.82 \\
\hline \multirow{5}{*}{3} & 1 & 2.78 & 0.87 & 0.24 & 4.85 & 4.30 & 0.65 & 0.20 & 0.06 & 0.91 & 0.89 \\
\hline & 2 & 3.73 & 1.12 & 0.37 & 6.64 & 5.73 & 0.65 & 0.20 & 0.06 & 0.91 & 0.86 \\
\hline & 3 & 6.40 & 1.65 & 0.44 & 10.44 & 8.71 & 0.73 & 0.19 & 0.05 & 0.97 & 0.83 \\
\hline & 4 & 5.44 & 1.43 & 0.41 & 9.66 & 7.99 & 0.68 & 0.18 & 0.05 & 0.91 & 0.83 \\
\hline & 6 & 4.35 & 1.04 & 0.20 & 7.28 & 5.98 & 0.73 & 0.17 & 0.03 & 0.93 & 0.82 \\
\hline \multirow{5}{*}{4} & 1 & 1.90 & 0.64 & 0.18 & 3.28 & 3.05 & 0.62 & 0.21 & 0.06 & 0.89 & 0.93 \\
\hline & 2 & 4.13 & 1.33 & 0.41 & 7.69 & 6.69 & 0.62 & 0.20 & 0.06 & 0.88 & 0.87 \\
\hline & 3 & 5.05 & 1.81 & 0.44 & 10.39 & 8.78 & 0.58 & 0.21 & 0.05 & 0.84 & 0.85 \\
\hline & 4 & 4.92 & $\begin{array}{l}1.01 \\
1.52\end{array}$ & 0.42 & 10.13 & 8.56 & 0.57 & 0.18 & 0.05 & 0.80 & 0.85 \\
\hline & 6 & 4.86 & 1.20 & 0.23 & 7.43 & 6.21 & 0.78 & 0.19 & 0.04 & 1.01 & 0.84 \\
\hline \multirow{5}{*}{5} & 1 & 2.68 & 0.97 & 0.25 & 5.71 & 5.15 & 0.52 & 0.19 & 0.05 & 0.76 & 0.90 \\
\hline & 2 & 4.07 & 1.24 & 0.34 & 6.88 & 6.05 & 0.67 & 0.20 & 0.06 & 0.93 & 0.88 \\
\hline & 3 & 4.51 & 1.46 & 0.35 & 8.85 & 7.36 & 0.61 & 0.20 & 0.05 & 0.86 & 0.83 \\
\hline & 4 & & $\begin{array}{l}1.40 \\
1.30\end{array}$ & 0.32 & 8.08 & 6.71 & 0.57 & 0.19 & 0.05 & 0.81 & 0.83 \\
\hline & 6 & 2. & 0.78 & $\begin{array}{l}. .14 \\
0.14\end{array}$ & 4.75 & 4.02 & 0.74 & 0.19 & 0.03 & 0.96 & 0.85 \\
\hline
\end{tabular}

*: SUM. $=($ Protein + Carbohydrate + Nucleic acid $) /$ VSS

Table 6 Results of suspended microbial composition analysis as a function of time.

\begin{tabular}{|c|c|c|c|c|c|c|c|c|c|c|}
\hline $\begin{array}{l}\text { Time } \\
\text { (week) }\end{array}$ & $\begin{array}{l}\text { Protein } \\
\left(\mathrm{mg} \cdot \mathrm{l}^{-1}\right)\end{array}$ & $\begin{array}{c}\text { Carbohydrate } \\
\left(\mathrm{mg} \cdot \mathrm{l}^{-1}\right)\end{array}$ & $\begin{array}{c}\text { Nucleic } \\
\text { acid (mg. } \text { l }^{-} \text {) }\end{array}$ & $\begin{array}{l}\text { MLSS } \\
\left(\mathrm{mg} \cdot \mathrm{l}^{-n}\right)\end{array}$ & $\begin{array}{l}\text { MLVSS } \\
\left(\mathrm{mg} \cdot \mathrm{l}^{-1}\right)\end{array}$ & $\begin{array}{r}\text { Protein } \\
\text { /MLVSS }\end{array}$ & $\begin{array}{c}\text { Carbohydrate } \\
\text { /MLVSS }\end{array}$ & $\begin{array}{l}\text { Nucleic acid } \\
\text { /MLVSS }\end{array}$ & SUM.* & MLVSS/MLSS \\
\hline 1 & 374 & 137 & 54 & 1120 & 853 & 0.44 & 0.16 & 0.06 & 0.66 & 0.76 \\
\hline 2 & 172 & 53 & 20 & 538 & 319 & 0.54 & 0.17 & 0.06 & 0.77 & 0.59 \\
\hline 3 & 95 & 27 & 13 & 348 & 203 & 0.47 & 0.13 & 0.06 & 0.66 & 0.58 \\
\hline 4 & 48 & 12 & 6 & 279 & 112 & 0.43 & 0.11 & 0.05 & 0.59 & 0.40 \\
\hline 6 & 84 & 21 & 9 & 340 & 137 & 0.61 & 0.15 & 0.07 & 0.83 & 0.40 \\
\hline
\end{tabular}

*: SUM. $=($ Protein + Carbohydrate + Nucleic acid $) /$ MLVSS 
遊微生物 $\left(88 \mathrm{mg}-\mathrm{VSS} ・ l^{-1}\right)$ とでは異なっている。その 際の初期比 DOC 除去速度 $\left(\mathrm{g}-\mathrm{DOC} \cdot \mathrm{g}^{-1}-\mathrm{VSS} \cdot \mathrm{h}^{-1}\right)$

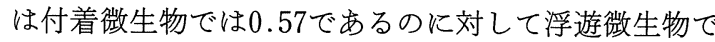
は1.05と1.8倍の值を示している。また両ケースとも $\mathrm{DOC}$ 濃度 $23 \mathrm{mg} ・ l^{-1}$ にて応が進行しなくなった。こ れは連続処理実験結果とほぼ同じ処理結果であり, 魚 肉エキスの色度成分由来の DOC と思われる。

\section{4. 考察}

\section{1 不織布の初期沪過特性}

Fig. 8 に不織布の初期沪過テストに抢けるSS 除去 率に与兄る目開き間隔の影響を示す。流入水 SS 濃度 $C_{\mathrm{in}}$ と流出水 $\mathrm{SS}$ 濃度 $C_{\mathrm{eff}}$ の関係については一般に清 澄沪過の SS 除去式として岩崎7の式(9)が用いられて いる。

$$
C_{\text {eff }} \cdot C_{\text {in }}^{-1}=\exp (-\lambda \cdot Z)
$$

ここで， $\lambda$ は阻止率であり $Z$ は沪層厚さを示す。清澄 沪過の SS 除去の主因子は，水流による沪材または被 沪過 SS 粒子表面への SS 粒子の接触でありその際の 水路の代表長さとして目開き間隔 $\alpha$ を採用し, 阻止率 を目開き間隔 $\alpha$ の逆数として表す。この際係数 $k$ は接 触効率を示す指標であると考兄られる。

$$
C_{\text {eff }} \cdot C_{\text {in }}{ }^{-1}=\exp \left(-k \cdot \alpha^{-1} \cdot Z\right)
$$

Fig. 8 中に示す実線は $k=1.6 \times 10^{-2}$ の場合の計算線 であり目開き間隔 $\alpha=0.54 \mathrm{~mm}$ の不織布担体の場合を 除き，実験值と良く符合している。 $\alpha=0.54 \mathrm{~mm}$ の場 合, 計算結果では拉よそ95\%の除去率となるが実験結 果では $86 \%$ となって扣り，その差異は他の場合と比較 して大きい。この理由は, 一般に SS 除去機構には沪材 表面にケーキと称するSS 層が形成されSSを捕集す

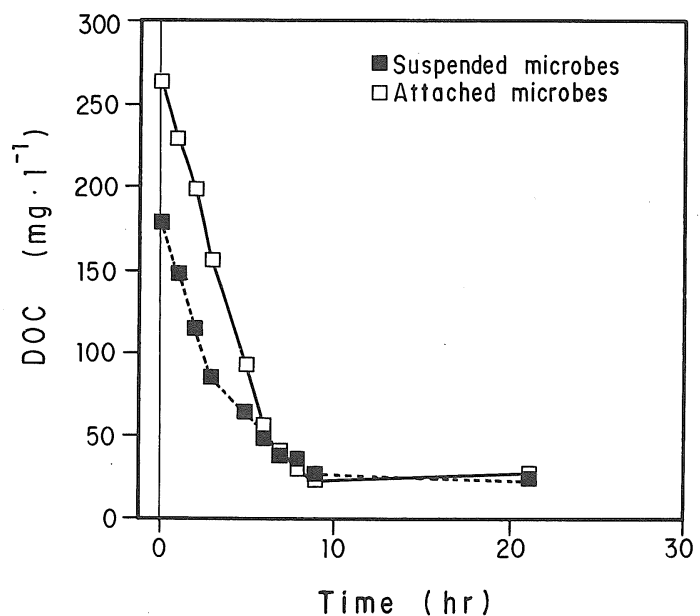

Fig. 7 Batch test results using attached and suspended microbes.
る表層沪過と沪材内部の空吵に SS を捕集する深層沪 過の二つのタイプがあるが，不織布担体の目開き間隔 によってどちらのタイプになるかが決定されるためと 考光られる。

Fig. 8 に示すように深層沪過が行われた担体 No. 1 ４（目開き間隔1.3〜 4.7mm）については式(10)に合致 したが，表層沪過が観察された担体 No. 5(目開き間隔 $0.54 \mathrm{~mm}$ )では, 沪材表面への SS 粒子の抑留に伴い不 織布担体の目開き間隔がさらに小さくなり，一種のふ るい作用が働くものの抑留物の剝離が扣こり，式(10)の 計算線より下回ったと考光られる。

4.2 微生物付着濃度と比表面積, 目開き間隔の関係 微生物付着が不織布担体の糸の表面にての及起こる と仮定すると不織布の付着 VSS 量を比表面積で除し て単位面積当りの付着 VSS 量が求められる。不織布 担体の糸の比表面積と付着 VSS 量の関係を Fig. 9 亿 示す。この結果を見ると担体の比表面積が大きくなれ ば付着 VSS 量が大きくなるといら一律的の関係はな いことがわかる。第 1 週目では比表面積約 $600 \mathrm{~m}^{-1}$ まで 比例関係にあるが，第 4 週目では比表面積 $400 \mathrm{~m}^{-1}$ まで 比例関係が認められるにとどまっている。

一方, 本実験の接触角 $73 \sim 104^{\circ}$ の 5 種類の平滑な板 状サンプルで求めた単位面積当りの付着量は，材質に よる有意差はなかったので平均付着量として表し Table 7 に示す。この理由は好気性微生物の場合バイ オポリマーの生成が多く固体表面の材質の差が影響さ れにくかったと考光られる。また平均付着量は 1 週間 までは経時的に増加したがそれ以降はサンプル採り上 げの際, 付着物が容易に剥離した。板状サンプルの 7

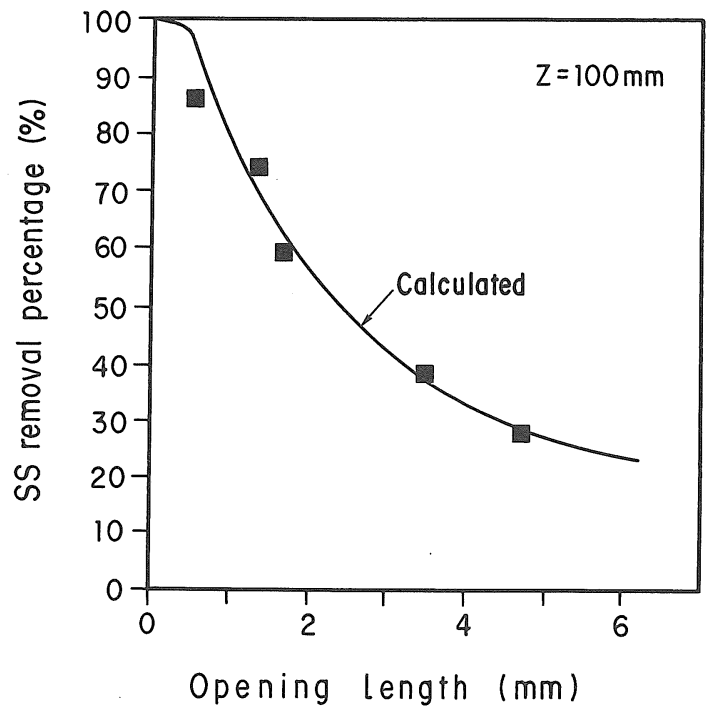

Fig. 8 Effect of opening length on SS removal. 
日目の平均付着量は $12 \mathrm{~g}-\mathrm{SS} \cdot \mathrm{m}^{-2}, 10 \mathrm{~g}-\mathrm{VSS} \cdot \mathrm{m}^{-2}$ で あった。

一般に文献で報告されている担体への微生物付着量 は基質の種類，濃度，負荷によりかなり大きな変動が ある。Costa Reisらのアルコール蒸留廃液希釈排水の 浸漬沪床法による高濃度廃水 $(B O D=2700-3250 \mathrm{mg}$ ・ $\left.l^{-1}\right)$ の好気性処理 $\left(\mathrm{COD}_{\mathrm{cr}}\right.$ 負荷 $\left.3.3-15.4 \mathrm{Kg} \cdot \mathrm{m}^{-3} \cdot \mathrm{d}^{-1}\right)$ では付着量 $33 \mathrm{~g}-\mathrm{SS} \cdot \mathrm{m}^{-2}$ が得られており ${ }^{8)}$ ，また回転円 板では 4 ステージ処理で付着量は 1 段目より 37.5 , $31.7,16.3,11.7 \mathrm{~g} \cdot \mathrm{m}^{-2}$ であった ${ }^{3)}$ と計算結果が示され ている。さらに富永らはハニカムチューブを用いた水 道原水中のケイ藻の除去で生物膜量が $2.8 \mathrm{~g} \cdot \mathrm{m}^{-2}$ で あったことを報告している9 。

そこで同一環境条件下で行われた本実験の不織布担 体と板状サンプルの付着量を比較すると, 比表面積 220 $\mathrm{m}^{-1}$ の不織布担体では 1 週目では $9.4 \mathrm{~g}-\mathrm{VSS} \cdot \mathrm{m}^{-2}$ とほ ぼ同じ值であり，不織布担体として比較的小さい比表 面積 $200 \mathrm{~m}^{-1}$ 程度では両者一致がみられた。しかし不織 布担体の比表面積が大きくなるにつれて表面積当りの 付着量は少なくなり, $600 \mathrm{~m}^{-1}$ では約 $6 \mathrm{~g}-\mathrm{VSS} \cdot \mathrm{m}^{-2}$, $2000 \mathrm{~m}^{-1}$ では約 $2.5 \mathrm{~g}-\mathrm{VSS} \cdot \mathrm{m}^{-2}$ と著しく減少した。こ の現象は比表面積の増大に伴い，目開き間隔が小さく なり不織布担体の表層での SS 捕捉が起り，この表層 沪過により不織布担体内部は十分に利用されていない ためであると考学られる。この傾向は 4 週目の結果に ついてもあてはまる。

このように比表面積が増加しても全付着 VSS 量は 大きくならない例として，粒状沪材を用いた生物膜沪

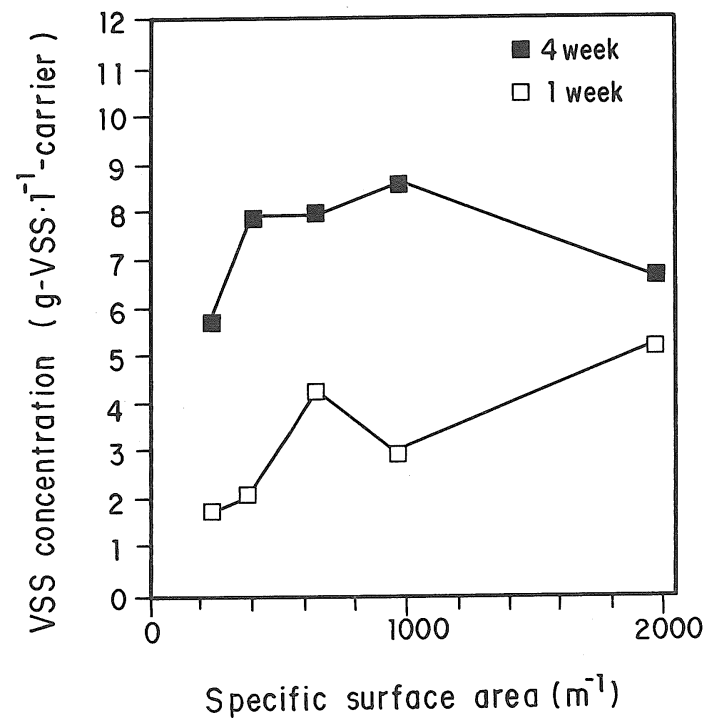

Fig. 9 Relationship between specific surface area and VSS concentration.
過法で推定比表面積約 60 ～ $180 \mathrm{~m}^{-1}$ の例 ${ }^{10)}$ が，またメカ ニズムは異なると思われるが，浸漬沪床法で比表面積 （範囲1000～2000 $\mathrm{m}^{-1}$ ） が増大すると BOD 除去速度が 低下することも報告されている ${ }^{11)} 。$

Fig. 6 に示したように不織布担体の目開き間隔に最 も微生物が高濃度に付着しやすい至適範囲が存在する ことがわかった。この理由は，目開き間隔が大きい場 合は不織布担体の微生物付着機構の第一段階である初 期沪過性能が劣るが不織布担体内部への微生物付着の 機会は増加する。一方目開さ間隔が小さい場合は表面 沪過が進行しやすくなり，不織布担体内部での微生物 付着の進行が遅くなるためである。したがって, 目開 き間隔を変えることにより両者を満足する至適範囲が 存在してくることがわかる。このように担体の目開き 間隔が微生物付着機構の初期沪過および微生物増殖を 支配している重要な因子であることが判明した。

\section{3 微生物の SEM 観察結果}

Fig. 10 に単繊維表面上に付着する微生物の走査型 顕微鏡写真 (SEM) を示す。本サンプルは浸漬 1 週間 の状態の生物膜形成初期段階を示して扣り，微生物が 繊維表面に付着するために粘着性物質（バイオポリ マー)を分泌し糸状に見觉る。なた，Fig.11には浸漬 6 週間の不織布上の付着微生物を示すが, 生物膜形成 完了乙微生物とバイオポリマーとが複雑に層を成して おり，流入水中の SS と思われるものが取り込まれて いるのがわかり，付着 VSS 量が必ずしも微生物量を 表現していないことが示唆される。両観察結果より単 層付着段階では微生物が主体となり付着しているが, 徐々に複層化してくるにつれ微生物, バイオポリマー, 排水中の SS が渾然一体となった複合物が形成されて いることが観察された。Fletcher, M.は単層生物膜と 複層化した生物膜とでは起りえる反応や捕捉機構が全 く異なるため，両者の差異を認識することが重要であ ると述べている ${ }^{12)}$ 。次に, 浮遊微生物を沪紙に沪過して 撮影したSEMを Fig.12 に示す。微生物がフロックを 形成するための粘着性物質が微生物の周りに観察で き, 付着微生物とは異なり流入水中の SS 等はフロッ クに取り込まれていない。また非フロック性の微生物 はSEM のサンプル固定化操作の際に流失した ${ }^{13)}$ と考

Table 7 Average attached biomass on five plate samples.

\begin{tabular}{|c|cc|c|}
\hline $\begin{array}{c}\text { Time } \\
\text { (day) }\end{array}$ & \multicolumn{2}{|c|}{ Average attached biomass } & VSS/SS \\
\hline 1 & $\mathrm{~g}-$ VSS $\left.\cdot \mathrm{m}^{-2}\right)$ & $\left(\mathrm{g}-\mathrm{SS} \cdot \mathrm{m}^{-2}\right)$ & \\
3 & - & 0.89 & - \\
7 & 3.68 & 3.81 & 0.96 \\
\hline
\end{tabular}




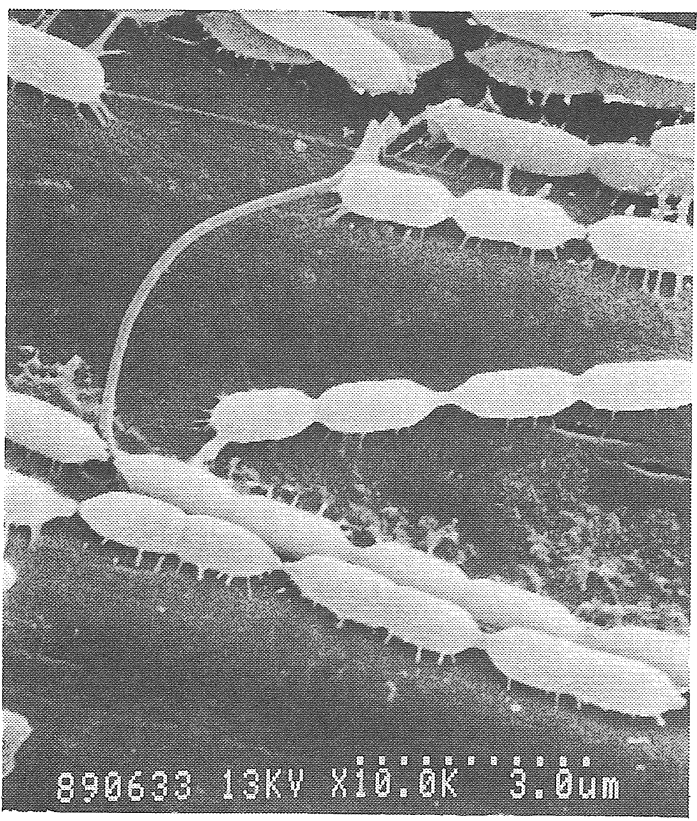

Fig. 10 SEM of initially attached microbes on a single thread surface.

えられる。

\section{4 微生物組成の比較}

付着微生物と浮遊微生物の SEM 観察結果が異なっ たため, 両者の微生物組成について検討した。Table 5, 6 に示したよらに，付着微生物の核酸/VSSの全不織 布担体の平均值は $5.0 \%$ あるが, 浮遊微生物の場合は 核酸/MLVSS の平均值は6.1\%である。浮遊微生物の 測定にはMLVSSを用いたため前述のように MLVSS 中に色度成分等由来の MLVSS が存在し, 実 際の核酸/VSS の值は6.1\%より高くなると推定され, 浮遊微生物は付着微生物より核酸の含有率がさらに高 くなると思われる。

この点を明確にするために，微生物の組成はタンパ ク質，炭水化物，核酸の各成分が主体になっているの で，この 3 成分を綾計して各成分の百分率として Table 8 によめた。各担体間での付着微生物の組成 の有意差は認め難いが，付着微生物の 3 成分の経時変 化をみるとタンパク質割合は増加し，炭水化物割合は 変化が余りなく，核酸割合は減少傾向を示しているの がわかる。全担体の平均付着微生物の組成はタンパク 質：炭水化物：核酸=73.1:21.3:5.6であるのに対 して浮遊微生物の組成は70.8:20.5:8.8 と核酸割合 が異なった値を示した。この結果より付着微生物のタ ンパク質割合の経時的増加は付着微生物がバイオポリ マーを分泌し担体に粘着しているために起り，それに 応じて核酸割合は経時的に減少したと考兄られる。こ

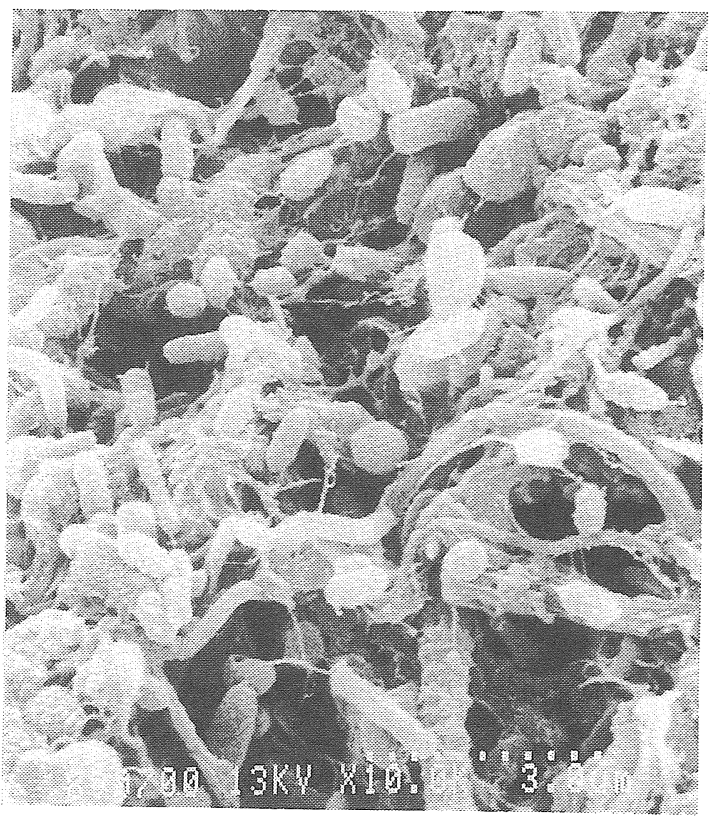

Fig. 11 SEM of attached microbes on nonwoven fabrics.

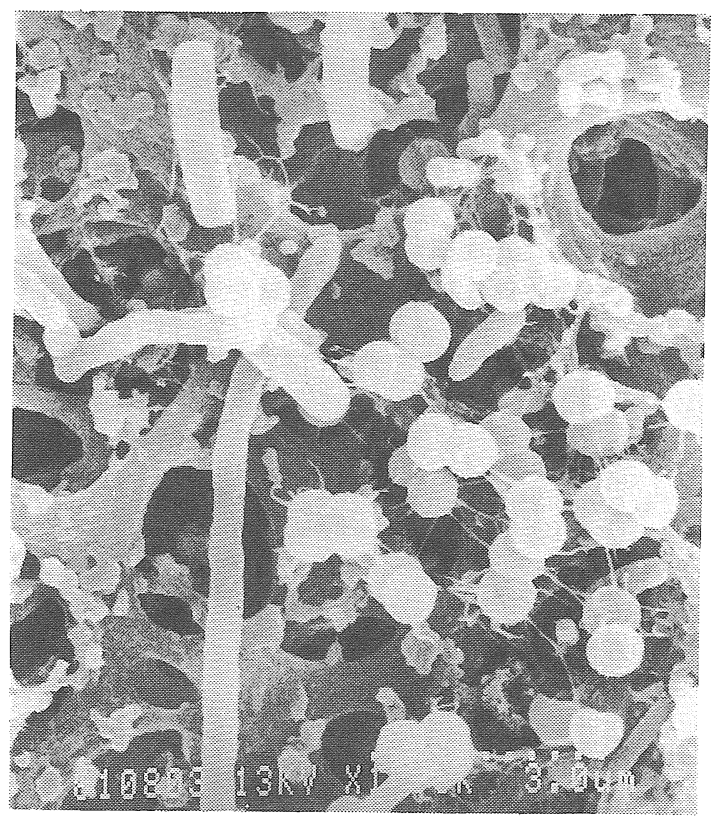

Fig. 12 SEM of suspended microbes on filter paper.

のよらに微生物の組成変化から付着微生物と浮遊微生 物とは動力学的に異なると推定された。

\section{5 動力学定数の比較}

浮遊微生物が微生物フロックとして存在しているこ とが SEM 観察により理解されたが，この浮遊微生物 


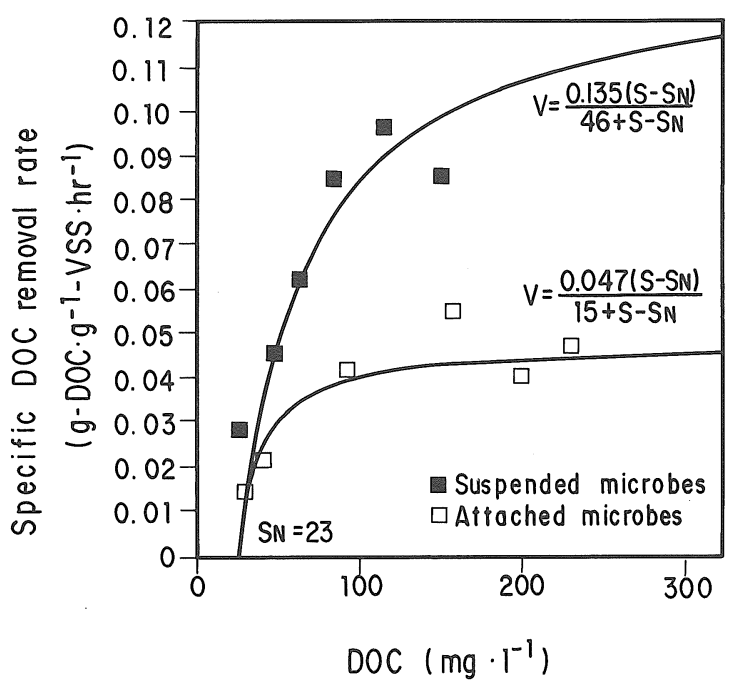

Fig. 13 Kinetic constants obtained from the relationship between DOC and specific DOC removal rate.

Table 8 Characteristics of microbial composition ratio.

\begin{tabular}{|c|c|c|c|c|c|}
\hline Microbes & $\begin{array}{l}\text { Carrie } \\
\text { number }\end{array}$ & $\begin{array}{l}\text { Time } \\
\text { (week) }\end{array}$ & $\begin{array}{c}\text { Protein } \\
(\%)\end{array}$ & $\begin{array}{c}\text { Carbohydrate } \\
(\%)\end{array}$ & $\begin{array}{l}\text { Nucleic } \\
\text { acid }(\not)\end{array}$ \\
\hline \multirow{5}{*}{ Attached } & \multirow{5}{*}{1} & 1 & 71.5 & 22.0 & 6.5 \\
\hline & & 2 & 73.9 & 19.2 & 6.9 \\
\hline & & 3 & 74.7 & 19.8 & 5.5 \\
\hline & & 4 & 72.0 & 22.6 & 5.4 \\
\hline & & 6 & 76.4 & 20.3 & 3.3 \\
\hline \multirow{4}{*}{ Attached } & \multirow{4}{*}{2} & 1 & 69.6 & 23.2 & 7.2 \\
\hline & & 2 & 75.5 & 18.0 & 6.5 \\
\hline & & 3 & 72.9 & 21.6 & 5.5 \\
\hline & & 4 & 74.3 & 20.8 & 4.9 \\
\hline \multirow{5}{*}{ Attached } & \multirow{5}{*}{3} & $\frac{0}{1}$ & $\frac{11.5}{71.5}$ & $\frac{10.0}{22.4}$ & $\frac{3.9}{6.2}$ \\
\hline & & 2 & 71.5 & 21.4 & 7.1 \\
\hline & & 3 & 75.4 & 19.4 & 5.2 \\
\hline & & 4 & 74.7 & 19.7 & 5.6 \\
\hline & & 6 & 77.7 & 18.7 & 3.6 \\
\hline \multirow{5}{*}{ Attached } & \multirow{5}{*}{4} & 1 & 69.6 & 23.6 & 6.8 \\
\hline & & 2 & 70.3 & 22.6 & 7.1 \\
\hline & & 3 & 69.2 & 24.7 & 6.1 \\
\hline & & 4 & 71.7 & 22.2 & 6.1 \\
\hline & & 6 & 77.3 & 19.0 & 3.7 \\
\hline \multirow{5}{*}{ Attached } & \multirow{5}{*}{5} & 1 & 68.7 & 24.9 & 6.4 \\
\hline & & 2 & 72.0 & 22.0 & 6.0 \\
\hline & & 3 & 71.3 & 23.1 & 5.6 \\
\hline & & 4 & 70.4 & 23.7 & 5.9 \\
\hline & & 6 & 76.6 & $\frac{19.9}{20 . ?}$ & $\frac{3.5}{0.5}$ \\
\hline \multirow{4}{*}{ Suspended } & & $\begin{array}{l}1 \\
2\end{array}$ & $\begin{array}{l}66.3 \\
70.3\end{array}$ & $\begin{array}{l}24.2 \\
21.6\end{array}$ & $\begin{array}{l}9.5 \\
8.1\end{array}$ \\
\hline & & 3 & 70.3 & 20.0 & 9.7 \\
\hline & & 4 & 73.3 & 18.3 & 8.4 \\
\hline & & 6 & 73.5 & 18.4 & 8. \\
\hline
\end{tabular}

は活性が低下し担体より剥離したものか，活性が高く 浮遊状態で生育しているのかを検討するために回分テ ストにより, 動力学定数を求めた結果を Fig. 13 に示 す。DOC 濃度が $23 \mathrm{mg} \cdot l^{-1}$ にて反応が進行しなかった 点よりMonod 式に生物難分解物質濃度 $S_{N}$ を考慮し た式(11)により動力学定数を算出した。

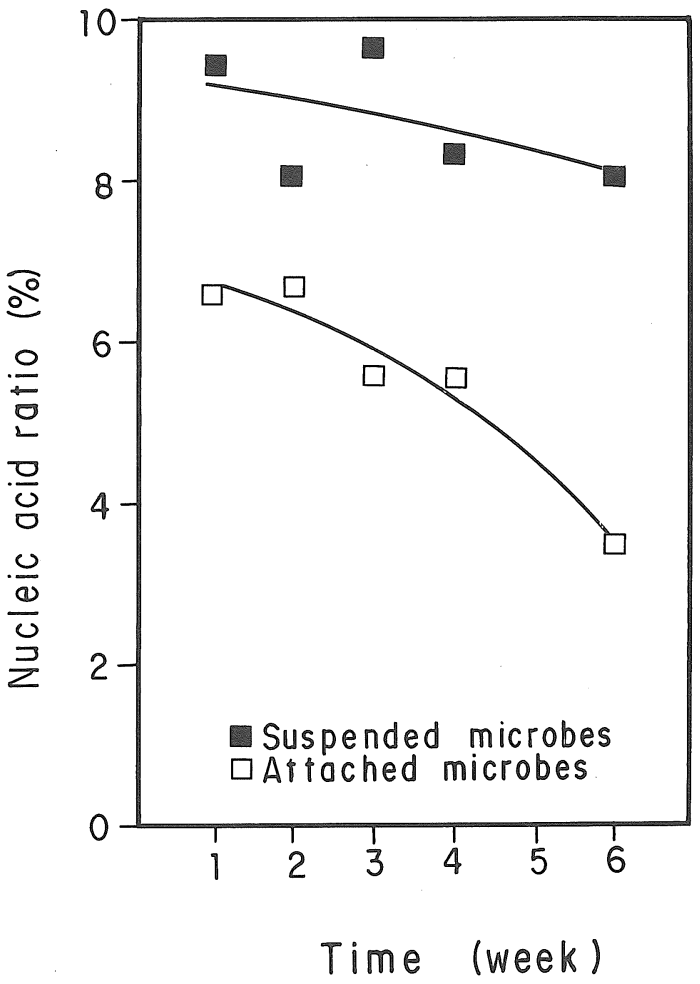

Fig. 14 Changes in nucleic acid ratio in microbes vs. time.

$$
V=V_{M A X} \cdot\left(S-S_{N}\right) \cdot\left(K_{N}+S-S_{N}\right)^{-1}
$$

ここで $S \quad$ : 基質濃度

$V$ : 比反応速度

$V_{M A X}$ : 最大比反応速度

$K_{S}$ : 飽和定数

$S_{N}$ : 生物難分解物質濃度

この結果を見ると浮遊微生物と付着微生物では飽和 定数が各々 $46 \mathrm{mg} \cdot l^{-1}, 15 \mathrm{mg} ・ l^{-1}$ とほぼ同レベルであ り，生物難分解物質を除いた基質に対する親和性は高 かった。最大比 DOC 除去速度は浮遊微生物では 0.135 $\mathrm{g}-\mathrm{DOC} \cdot \mathrm{g}^{-1}-\mathrm{VSS} \cdot \mathrm{h}^{-1}$, 付着微生物では0.047g-DOC・ $\mathrm{g}^{-1}-\mathrm{VSS} \cdot \mathrm{h}^{-1}$ となり浮遊微生物と付着微生物の比は 2.8倍であった。両テストとも完全混合状態で実施さ れ，微生物フロックの大きさもほぼ同等に調整したた め，両者の差異は基質の拡散律速とは考光られない。 SEM 観察結果でもわかるよらに付着微生物中には $\mathrm{SS}$ 含有し不活性物質が付着 VSS 量に含まれてい ることも反応速度の低下の一因と考えられる。

一方, Table 8 の浮遊微生物々付着微生物の組成分 析結果の核酸割合に差異がある点に注目し，両者の核 酸割合の経時変化を Fig.14 に示す。第 1 週目より, 核 酸割合は浮遊微生物の汪らが高いが，付着微生物では 
時間の経過とともに核酸割合が低下してきている。第 6 週目の両者の核酸割合の比は浮遊微生物は付着微生 物の 2.3 倍であった。両微生物の最大比 DOC 除去速度 の比率は2.8倍であったことから核酸割合の比が真の 微生物量の比を表していると考えられる。この点につ いて, 李らは嫌気性消化に执いて DNA を用いて微生 物量を算定することを提案している ${ }^{14)}$ 。

以上のように，生物膜法での浮遊微生物は活性が高 く浮遊, 生育していることがわかった。しかしながら, 一般に生物膜法の反応槽内に损ける付着微生物量と浮 遊微生物量を比較すると 2 桁違らため, 生物膜法での 反応速度は付着微生物濃度により決定させることとな る。

\section{5.まとめ}

不織布担体の好気性微生物の付着機構について実験 的検討を行い次のことがわかった。

1) 不織布の目開き間隔により表層沪過执よび深層 沪過の初期沪過特性が支配され，ぬた，生物膜形成， 微生物増殖の過程に影響を与えた。

2 ）不織布の比表面積の小さい範囲では 2 次元の板 状サンプルの微生物付着量と整合性があったしかし， さらに大きな比表面積の範囲では微生物付着量は比例 的に増加せず，最大の微生物付着量はある限定された 不織布の目開き間隔の範囲に存在することが判った。

3 ) 付着微生物と浮遊微生物の SEM 観察結果より 剥離した浮遊微生物はフロックを形成して和り, 一方 付着微生物はバイオポリマー，排水中の SSとともに 複雑な層を成していることが判った。

4 ) 微生物組成をタンパク質, 炭水化物, 核酸の含 有率を用いて検討した結果, 付着微生物と浮遊微生物 の微生物組成の差異は, 動力学定数に影響を与文, 核 酸割合の比が真の微生物量の比を表すことがわかっ た。

謝辞 本研究の遂行にあたり, 当研究開発センターの
野村久志氏の尽力に心より感謝の意を表す。 （原稿受理 1990年 4 月 19 日）

\section{参 考 文 献}

1) Tsezos, M. and Benedek, A. (1980) Romoval of organic substances by biologically activated carbon in a fluidizedbed reactor, J. WPCF, 52, 528-586.

2 ) Shimodaira, C. and Yushina, Y. (1983) Biological waste water treatment with downflow fluidized bedreactor, Proc. of the 3rd Pacific Chem. Eng. Congress, 4 237-242, Korean Institute of Chem. Engineers.

3）洞沢勇編（1982）生物膜法, 思考社, 東京。

4) Dahlgren, C., Elwing, H. and Magnusson, K.E. (1986) Comparison of contact angles calculated from the diameter of sessile drops and submerged air bubbles in contact solid surface, Colloids and Surfaces, 17, 295-303.

5 ) 森崎久雄, 服部黎子 (1986) 界面之微生物, 50-61, 学会出版 センター, 東京。

6 ) 微生物研究法懇談会編 (1975) 微生物学実験法, 225-264, 講 談社, 東京.

7 ) 岩崎富久 (1937) 濾過阻止率の計算, 土木学会誌, 24, 8 .

8 ) Costa Reis, L.G. and Sant'Anna Jr G.L. (1985) Aerobic treatment of concentrated wastewater in a submerged bed reactor, Water Res., 19, 1341-1345.

9 ）富永昇一, 秋山広毅 (1983) 茨城県企業局に打ける生物処理 の実用規模実験, 用水と廃水，25，62-70.

10）久新正三郎，東野宏昭，野中信一（1989）生物膜沪過法に沶 ける沪材粒径の違いによる処理性能比較実験, 環境技術, 18, 102-104.

11）池田康郎, 藤江幸一, 浦野紘平（1989）浸漬沪床による有機 性排水の処理(第 7 報), 第23回水質污濁研究会講演集, 49-50.

12) Fletcher, M. (1984) Comparative physiology of attached and free-living bacteria., Microbial adhesion and aggregation, ed. Marshall, K.C., 223-232, Springer-Verlag, New York.

13) Wheatley, A.D. (1981) Investigations into the ecology of biofilms in waste treatment using scanning electron microscopy, Environ. Thechnol. Letters, 2, 419-424.

14) 李光浩, 野池達也(1989), 嫌気性消化に打ける微生物量と動 力学定数算定, 下水道協会誌, $26(9), 28-34$. 


\section{論文要旨}

\section{不織布担体の好気性微生物付着機構に関する研究}

\section{油科 嘉則* 長谷川 潤*}

* 千代田化工建設株式会社研究開発センター

〈水質污濁研究 Vol. 13 No.7 (1990) pp. 431 440〉

生物膜法による排水処理において微生物担体として合成樹脂，セラミック，砂などが従来より用いられてき た。反応槽中の微生物濃度は生物処理性能に関与するため微生物担体はその比表面積を増加させることに重点 が置かれてきた。微小粒状担体を用いた流動床法はその一例である。合成樹脂不織布は糸表面への微生物付着 および繊維が織りなす立体空間での微生物の増殖により高効率な微生物担体と考えられる。しかしながら，好 気性担体としての不織布の応用に関する報告は少ない。そこで不織布の初期沪過テスト，槽内での初期微生物 付着テストおよび微生物増殖テストを実施し，不織布への好気性微生物付着機構を明らかにするために実験的 検討を行った。その結果，付着微生物濃度に関して比表面積よりはむしろ不織布の目開き間隔に至適範囲が存 在することが判った。また浮遊微生物と付着微生物の組成の差異が動力学定数に影響を与えた。

\section{生物学的脱リン過程の二相生物モデルによるシミュレーション}

\section{尹照熙* 鈴木 基之*}

* 東京大学生産技術研究所

〈水質污濁研究 Vol. 13 No.7 (1990) pp. 441 448〉

嫌気・好気繰り返し法による生物学的脱リンにおける 1 サイクル中のリンおよび有機物の濃度変化を記述す るために，污泥がその脱リン特性に基づき，脱リン性微生物と非脱リン性微生物の二相から構成するものとし， 有機物の濃度影響を考慮したモデルを提案した。

1 サイクルの間のリンの放出，摂取挙動は脱リン性微生物，嫌気状態での投入有機物などに大きく影響され る。また，槽内の有機物は嫌気状態で微生物によりほほ攝取されている。実験による濃度変化の測定結果は， 簡単なモデルにより，ほぼ正確に表し得ることが確認された。 